\title{
Studies on Insect Pests of Drumstick and their Natural Enemies in Northern Dry Zone Climate of Karnataka, India
}

\author{
K. B. Rachana ${ }^{1}$, S. B. Jagginavar ${ }^{1 *}$, H. T. Prakash ${ }^{2}$ and S. A. Biradar ${ }^{2}$ \\ ${ }^{1}$ Department of Agricultural Entomology, College of Agriculture, India \\ ${ }^{2}$ ICAR-Krishi Vigyan Kendra, Vijayapur, Karnataka, UAS, Dharwad, (Karnataka), India \\ *Corresponding author
}

\section{A B S T R A C T}

\begin{tabular}{|l|}
\hline Ke y w o r d s \\
$\begin{array}{l}\text { Drumstick, Noorda } \\
\text { blitealis, Thrips, } \\
\text { Natural enemies etc }\end{array}$ \\
\hline Article Info \\
$\begin{array}{l}\text { Accepted: } \\
16 \text { November } 2020 \\
\text { Available Online: } \\
\text { 10 December } 2020\end{array}$ \\
\hline
\end{tabular}

\section{Introduction}

Drumstick (Moringa oleifera L.) is indigenous to our country, Pakistan and Nepal borders, it is widely cultivated in other parts of both the old and new world tropics, including Asia, Africa and South and Central America. Different types of soil and forest soil which is rich in humous become the most ideal for growth of drumstick. In India drumstick is locally known as 'Nuggekai' (Kannada). In India drumstick is attacked by different insect pests, attacking at the various stages of this tree viz., leaf eating caterpillars (Noorda blitealis Walker, Crambidae: Lepidoptera, Eupterote mollifera Walker,
Eupterotidae: Lepidoptera and Tetragonia siva Lef., Metanastria hyrtaca Cramer, Lasiocampidae: Lepidoptera), bud worm (Noorda moringae Tams., Crambidae: Lepidoptera), bark eating caterpillar (Indarbela quadrinotata Walker, Indarbelidae: Lepidoptera), Stem borers (Indarbela tetraonis Moore, Indarbelidae: Lepidoptera and Diaxenopsis apomecynoides Bruning, Cerambycida: Coleoptera), longhorn beetle (Batocera rubus L., Cerambycidae: Coleoptera), ash weevils (Myllocerus discolor var. variegates Boheman, M. delicatulus and M. viridanus, Curculionidae: Coleoptera), aphids (Aphis craccivora Koch, Aphididae: Hemiptera), Tea mosquito bug (Helopeltis 
antonii Sign., Miridae: Hemiptera), bud midges (Stictodiplosis moringae Mani, Cecidomyiidae: Diptera), scale insects (Diaspidiotus sp., Diaspididae: Homoptera and Ceroplastodes cajani Mask, Coccidae: Hemiptera), Pod fly (Gitona distigma Meigen, Drosophilidae: Diptera) (Kader and Shanmugavelu, 1982; Ragumoorthi and Arumugum, 1992; Kalia and Joshi, 1997; Munj et al., 1998; Usha et al., 2010; David and Ramamurthy, 2016). With this background, the present study was taken up to study the status of drumstick insect pests and their natural enemies in Northern dry zone of Karnataka.

\section{Materials and Methods}

The experiment was conducted in kharif season, 2018 at College of Agriculture, Vijayapur. Established drumstick (PKM-1 Variety) plantation of one and half year old was used to study the population dynamics of insect pests and their natural enemies.

The observations on the pest incidence were recorded at weekly interval from ten randomly selected plants. Simultaneously the beneficial fauna was also being recorded and mean data was calculated. Observation on leaf eating caterpillar, N.blitealis, thrips and predators were recorded on ten randomly selected plants and expressed as mean population of insects/5 branches. The observation on parasitoids was taken by collecting the larvae from the field on respective SMW (Standard Meteorological Week) and kept in rearing cages to observe for parasitoids emergence, later the per cent parasitisation was worked out by using the formula,

$$
\text { Per cent parasitisation }=\quad \frac{\text { Number of parasitoid emerged }}{\text { Total number of larvae collected }} \times 100
$$

\section{Results and Discussion}

The activity of leaf eating caterpillar was observed throughout the year. During study period the population was ranged from 1.12 to 10.24 larvae per five branches, respectively. However, the maximum larval population (10.24 larvae/plant) was recorded during $51^{\text {st }}$ Standard Meteorological Week of December, while minimum population (1.12 larve/plant) was recorded during $22^{\text {nd }}$ Standard Meteorological Week of May (Fig. 1). The present findings are similar with the results of Munj et al., (1998) who reported Noorda blitealis Walker infestation on drumstick. Defoliation occurred in three peak periods, first from July to August, second on October and third on January. Activity of pest was noticed throughout the year and the highest population was noticed in January while least population was noticed from May to June. These findings are in accordance with the results of Butani and Verma (1981) recorded Noorda blitealis Walker causes maximum damage on drumstick during March to April and December to January. Mahesh and Kotikal (2014) observed severe infestation of Noorda blitealis Walker on drumstick. It caused 100 per cent foliage damage. Activity of $N$. blitealis was noticed throughout the year. Maximum (11.2 larvae per branch) larval population was noticed during second fortnight of April and 7.8 larvae per branch were noticed during second fortnight of October.

The drumstick infesting thrips species identified as two phytophagous thrips, Euphysothrips subramanii and Exothrips hemavarna (Ramakrishna and Margabandhu) (Thysanoptera: Thripidae) and one was predatory thrips, Franklinothrips sp. (Thysanoptera : Aeolothripidae). The activity of thrips was observed throughout the year and population was ranged from 2.56 to 16.40 thrips per five branches which was coincided 
during $23^{\text {rd }}$ Standard Meteorological Week of June to $22^{\text {nd }}$ Standard Meteorological Week of May. Maximum population (16.40/ 5 branches) was recorded during $20^{\text {th }}$ Standard Meteorological Week of May (Fig. 1). The present finding is in accordance with Bana et al., 2018 reported Exothrips hemavarna Ramakrishna and Margabandhu in mango and this thrips was more active in the months of February-March (vegetative and flowering cum fruit setting stages). Arakaki and
Okajima, 1998 reported Franklinothrips sp. association with prey on economically important crops viz., avocados, beans, cacao, chillies, citrus, coffee, eggplant and melons. Thrips, Franklinothrips orizabensis Johansen extensively used for the study of its biology and predatory efficacy on avocado thrips, Scirtothrips perseae Nakahara (Thysanoptera: Thripidae). In Europe, F. orizabensis used as an efficient bio-control agent against thrips, $S$. perseae.

Table.1 Population dynamics of predators during 2018-19

\begin{tabular}{|c|c|c|c|c|}
\hline \multirow[t]{2}{*}{ Month } & \multirow{2}{*}{ SMW } & \multicolumn{3}{|c|}{ Mean number of insects/ branch $(n=5)$} \\
\hline & & Coccinellids & Praying mantid & Spiders \\
\hline \multirow[t]{4}{*}{ June } & 23 & 0.00 & 0.02 & 0.02 \\
\hline & 24 & 0.00 & 0.00 & 0.02 \\
\hline & 25 & 0.02 & 0.02 & 0.00 \\
\hline & 26 & 0.00 & 0.00 & 0.00 \\
\hline \multirow[t]{5}{*}{ July } & 27 & 0.02 & 0.00 & 0.02 \\
\hline & 28 & 0.08 & 0.00 & 0.00 \\
\hline & 29 & 0.00 & 0.00 & 0.04 \\
\hline & 30 & 0.00 & 0.02 & 0.00 \\
\hline & 31 & 0.02 & 0.00 & 0.02 \\
\hline \multirow[t]{4}{*}{ August } & 32 & 0.00 & 0.00 & 0.00 \\
\hline & 33 & 0.04 & 0.00 & 0.06 \\
\hline & 34 & 0.02 & 0.02 & 0.04 \\
\hline & 35 & 0.06 & 0.04 & 0.00 \\
\hline \multirow[t]{4}{*}{ September } & 36 & 0.00 & 0.00 & 0.00 \\
\hline & 37 & 0.04 & 0.00 & 0.02 \\
\hline & 38 & 0.02 & 0.00 & 0.00 \\
\hline & 39 & 0.00 & 0.00 & 0.02 \\
\hline \multirow[t]{5}{*}{ October } & 40 & 0.02 & 0.00 & 0.02 \\
\hline & 41 & 0.04 & 0.00 & 0.06 \\
\hline & 42 & 0.00 & 0.02 & 0.00 \\
\hline & 43 & 0.02 & 0.00 & 0.00 \\
\hline & 44 & 0.00 & 0.00 & 0.00 \\
\hline \multirow[t]{4}{*}{ November } & 45 & 0.00 & 0.02 & 0.04 \\
\hline & 46 & 0.00 & 0.00 & 0.00 \\
\hline & 47 & 0.00 & 0.00 & 0.02 \\
\hline & 48 & 0.00 & 0.00 & 0.06 \\
\hline \multirow[t]{2}{*}{ December } & 49 & 0.00 & 0.00 & 0.04 \\
\hline & 50 & 0.00 & 0.00 & 0.00 Cont \\
\hline
\end{tabular}




\begin{tabular}{|c|c|c|c|c|}
\hline & 51 & 0.00 & 0.00 & 0.08 \\
\hline & 52 & 0.00 & 0.00 & 0.02 \\
\hline \multirow[t]{5}{*}{ January } & 1 & 0.00 & 0.00 & 0.00 \\
\hline & 2 & 0.02 & 0.00 & 0.04 \\
\hline & 3 & 0.00 & 0.00 & 0.02 \\
\hline & 4 & 0.00 & 0.00 & 0.06 \\
\hline & 5 & 0.02 & 0.02 & 0.00 \\
\hline \multirow[t]{4}{*}{ February } & 6 & 0.00 & 0.00 & 0.00 \\
\hline & 7 & 0.02 & 0.00 & 0.00 \\
\hline & 8 & 0.00 & 0.02 & 0.00 \\
\hline & 9 & 0.06 & 0.00 & 0.00 \\
\hline \multirow[t]{4}{*}{ March } & 10 & 0.00 & 0.02 & 0.00 \\
\hline & 11 & 0.04 & 0.00 & 0.00 \\
\hline & 12 & 0.02 & 0.00 & 0.00 \\
\hline & 13 & 0.00 & 0.00 & 0.02 \\
\hline \multirow{5}{*}{ April } & 14 & 0.02 & 0.00 & 0.00 \\
\hline & 15 & 0.00 & 0.02 & 0.02 \\
\hline & 16 & 0.00 & 0.00 & 0.00 \\
\hline & 17 & 0.00 & 0.00 & 0.00 \\
\hline & 18 & 0.00 & 0.00 & 0.00 \\
\hline \multirow[t]{4}{*}{ May } & 19 & 0.00 & 0.02 & 0.02 \\
\hline & 20 & 0.00 & 0.00 & 0.00 \\
\hline & 21 & 0.00 & 0.00 & 0.04 \\
\hline & 22 & 0.00 & 0.00 & 0.00 \\
\hline \multicolumn{2}{|c|}{ Mean } & 0.01 & 0.01 & 0.02 \\
\hline \multicolumn{2}{|c|}{ S.D. \pm} & 0.02 & 0.01 & 0.02 \\
\hline
\end{tabular}

SMW: Standard Meteorological Week

Table.2 Population status of parasitiods and per cent parasitisation

\begin{tabular}{|c|c|c|c|c|}
\hline $\begin{array}{c}\text { S1 } \\
\text { No. }\end{array}$ & SMW & $\begin{array}{c}\text { No. of larvae collected } \\
\text { (N. blitealis) }\end{array}$ & $\begin{array}{c}\text { No. of } \\
\text { emerged } \\
\text { parasitoids }\end{array}$ & $\begin{array}{c}\text { Parasitisation } \\
(\mathbf{\%})\end{array}$ \\
\hline $\mathbf{1}$ & 32 & 20 & 2.00 & 10.00 \\
\hline $\mathbf{2}$ & 33 & 20 & 1.00 & 5.00 \\
\hline $\mathbf{3}$ & 34 & 20 & 1.00 & 5.00 \\
\hline $\mathbf{4}$ & 35 & 20 & 3.00 & 15.00 \\
\hline $\mathbf{5}$ & 49 & 20 & 2.00 & 10.00 \\
\hline $\mathbf{6}$ & 50 & 20 & 2.00 & 10.00 \\
\hline $\mathbf{7}$ & 51 & 20 & 1.00 & 5.00 \\
\hline $\mathbf{8}$ & 52 & 20 & 3.00 & 15.00 \\
\hline $\mathbf{9}$ & 4 & 20 & 2.00 & 10.00 \\
\hline $\mathbf{1 0}$ & 5 & 20 & 2.00 & 10.00 \\
\hline & & Mean & $\mathbf{1 . 9}$ & \\
\hline & & S.D. $\mathbf{E}$ & $\mathbf{0 . 7 4}$ & \\
\hline
\end{tabular}


Fig Population dynamics of leaf eating caterpillar, Noorda blitealis

Walker and thrips* during 2018-19

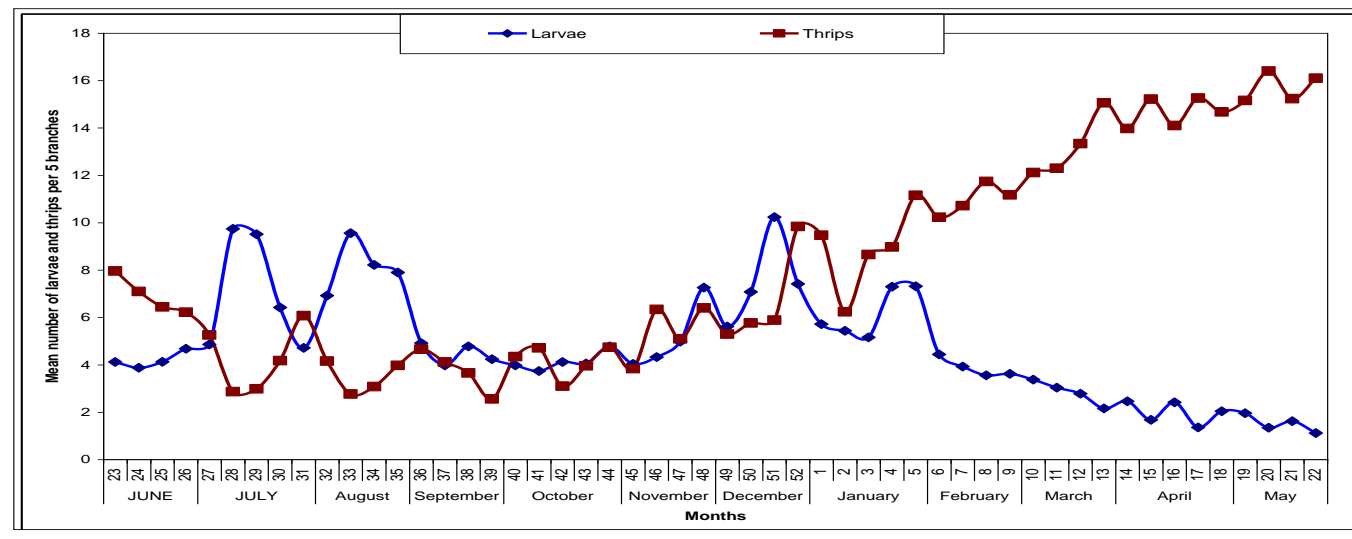

SMW: Standard Meteorological Week

*Phytophagus thrips, Euphysothrips subramanii and Exothrips hemavarna (Ramakrishna and Margabandhu) and predatory thrips, Franklinothrips sp.

The activity of coccinellids was observed during $25^{\text {th }}$ Standard Meteorological Week to $14^{\text {th }}$ Standard Meteorological Week. The population was ranged from 0.02 to 0.08 beetles per five branches. The maximum coccinellids (0.08) were recorded during $28^{\text {th }}$ Standard Meteorological Week of July. Similarly activity of praying mantid was observed throughout the year and population was ranged from 0.02 to 0.04 per five branches. The maximum praying mantid (0.04) were recorded during $35^{\text {th }}$ Standard Meteorological Week of August. The maximum number of spiders $(0.08$ spiders per five branches) was recorded during $51^{\text {st }}$ Standard Meteorological Week of December (Table 1). The findings are in accordance with Mahesh et al., (2013) reported that both grubs and adults of Cheilomenes sexmaculata Fabricius were predating upon aphids on drumstick and activity of $C$. sexmaculata was noticed during August and December. Preying mantids were predating upon lepidopteran caterpillars throughout the year. Spiders were observed as effective general predators in drumstick ecosystem. They fed on lepidopteran caterpillars, $N$. blitealis and $N$. moringae and their activity was noticed throughout the year. The study are in similar with Kumari et al., (2015) recorded predators viz., Green lace wing
(Chrysoperla zastrowii simili Stephens), lady bird beetle (Menochilus sexmaculatus Fabricius), praying mantid (Anaxarcha limbata Goglio Toss), pentatomid bug (Eocanthecona furcellata Wolf) and 13 species of spiders as natural enemies in drumstick ecosystem.

The major parasitoid on leaf eating caterpillar was Braconid sp. which was observed when the large number of larvae $(n=20)$ were collected in respective Standard Meteorological Week. This braconid was yellow in colour and the range of parasitoid emerged was 1-3 with an average of $1.9 \pm 0.74$. Most of the parasitoid emerged in early instar stage of the $N$. blitealis (Table 2). The present study is in accordance with Kumari et al., (2015) recorded the parasitoid like Agathis sp. Braconidae, were associated with eggs and early instars larvae of $N$. blitealis.

In conclusion the results on population dynamics of leaf eating caterpillar, $N$. blitealis revealed that the pest was found to be active throughout the year. The larval population was ranged from 1.12 to 10.24 per five branches with the maximum population (10.24) was recorded during $51^{\text {st }}$ Standard Meteorological Week of December. The thrips activity was observed throughout the year. The population 
was ranged from 2.56 to 16.40 thrips per five branches which was coincided during $23^{\text {rd }}$ Standard Meteorological Week of June to $22^{\text {nd }}$ Standard Meteorological Week of May. The population of coccinellids was ranged from 0.02 to 0.08 beetles per five branches which were coincided during $25^{\text {th }}$ Standard Meteorological Week of June to $14^{\text {th }}$ Standard Meteorological Week of April. The maximum coccinellids (0.08) were recorded during $28^{\text {th }}$ Standard Meteorological Week of July. The maximum praying mantid (0.04) were recorded during $35^{\text {th }}$ Standard Meteorological Week of August. The maximum number of spiders ( 0.08 spiders per five branches) was recorded during $51^{\text {st }}$ Standard Meteorological Week of December. Parasitoid on leaf eating caterpillar was Braconid sp. and the range of parasitoid emerged was 1 to 3 with 5 to 15 per cent parasitisation.

\section{References}

Arakaki, N. and Okajima, S., 1998, Notes on the biology and morphology of a predatory thrips, Franklinothrips vespiformis (Crawford) (Thysanoptera: Aeolothripidae): First record from Japan. Entomol. Sci., 1: 359-363.

Bana, J. K., Sushil, K. and Sharma, H., 2018, Diversity and nature of damage of mango insect pests in south Gujarat ecosystem J. Entomol. Zool. Stud., 6(2): 274-278.

Butani, D. K. and Verma, S., 1981, Insect pests of vegetable and their control: Drumstick. Pesticides., 15 (10) : 29-31.

David, B.V. and Ramamurthy, V. V., 2016, Elements of Economic Entomology. Eighth edition. Brillion Publishing, New York-New Delhi, pp. 147-148.
Kader, M. M. and Shanmugavelu, K. G., 1982, Studies on performance of annual drumstick Moringa pterygosperma Goertn at Coimbatore. South Indian Hort., 30: 95-98.

Kalia, S. and Joshi, K. C., 1997, Efficacy of foliar spraying of three varietal strains of Bacillus thuringiensis against the moringa defoliator Noorda blitealis Tams. (Lepidoptera: Pyralidae). Indian J. Plant Prot., 25(1): 65- 66.

Kumari, M. S. B., Kotikal, Y. K., Narabenchi, G. and Nadaf, A. M., 2015, Bio-efficacy of insecticides, botanicals and biopesticide against the leaf eating caterpillar, Noorda blitealis Walker on drumstick. Karnataka J. Agric. Sci., 28 (2): 193-196.

Mahesh, M. and Kotikal, Y. K., 2014, Studies on insect pests of drumstick, Moringa oliefera Lamk. Indian J. Plant Prot., 42: 461-464.

Mahesh, M., Kotikal, Y. K. and Madalageri, M. B., 2013, Studies on natural enemies of insect pests of drumstick. J. Biol. Control, 27(4): 336-339.

Munj, A. Y., Patil, P. D. and Godase, S. K., 1998, Biology of drumstick leaf eating caterpillar, Noorda blitealis Walker. Pestology, 22: 18-21.

Ragumoorthi, K. N. and Arumugam, R., 1992, Control of moringa fruitfly, Gitona sp., and leaf caterpillar, Noorda blitealis Walker with insecticides and botanicals. Indian J. Plant. Prot., 20: 6165.

Usha, R.B., Suresh K., and Sundaram, R., 2010, Major insect pests of Moringa and their management, "Moringa a Nature's Gift, Coimbatore, pp.54-59.

\section{How to cite this article:}

Rachana, K. B., S. B. Jagginavar, H. T. Prakash and Biradar, S. A. 2020. Studies on Insect Pests of Drumstick and their Natural Enemies in Northern Dry Zone Climate of Karnataka, India. Int.J.Curr.Microbiol.App.Sci. 9(12): 2175-2180. doi: https://doi.org/10.20546/ijcmas.2020.912.257 